\title{
HPV detection in oral carcinomas
}

\author{
Detecção do HPV em carcinomas orais
}

Aurora Karla de Lacerda Vidal'; Arnaldo de França Caldas Júnior²; Roberto José Vieira de Mello;

Virgínia Ribes A. Brandão ${ }^{4}$; Getúlio Isidoro da Rocha ${ }^{5}$; Eliane Taromaru ${ }^{6}$

\begin{abstract}
key words abstract
Oral cancer

HPV

The authors set out in this study to verify the presence of low- and high-risk DNA of human papillomavirus (HPV) in oral cancer by means of the hybrid capture Digene ${ }^{\circledR}$ test (São Paulo-SP, Brazil) in smears from exfoliative cytology and also to compare the findings with those of conventional light microscopy Exfoliative cytology (hematoxylin-eosin (HE)/Papanicolaou). Forty individuals gave their written informed consent to partiHybrid capture cipate in the study and also had their clinical data analyzed. The 40 exfoliative cytology examinations performed to date produced the following results: 29 (72.5\%) negative for low- and high-risk HPV-DNA; nine (22.5\%) positive for low- and high-risk HPV-DNA; one (2.5\%) positive for low-risk HPV-DNA; and one $(2.5 \%)$ positive for high-risk HPV-DNA. There was agreement among the findings for the presence of DNA-HPV for both exfoliative cytology (smear to hybrid capture Digene ${ }^{\circledR}$ test and the cytological smear readings made by conventional light microscopy). It was therefore concluded that the HPV virus may be a cocarcinogen of the mouth cancer as it is in the cervix cancer.
\end{abstract}

resumo

Os autores buscaram verificar, neste estudo, a presença do papilomavírus humano (HPV) de baixo e de alto risco em carcinomas orais através do teste de captura híbrida Digene ${ }^{\circledast}$ (São Paulo-SP, Brasil) em amostras colhidas pela citologia esfoliativa bucal e, ainda, avaliar comparativamente as referidas leituras com alterações celulares indicativas deste vírus obtidas com a interpretação citológica óptica convencional (hematoxilinaeosina (HE)/Papanicolaou). Quarenta indivíduos concordaram, espontaneamente, através de assinatura do termo de consentimento livre e esclarecido, em participar da pesquisa, e seus dados clínicos foram analisados. Entre as 40 amostras provenientes da citologia esfoliativa 29 (72,5\%) mostraram-se negativas para presença de HPV-DNA de baixo e de alto risco; nove (22,5\%) foram positivas para o HPV-DNA de baixo e de alto risco; uma $(2,5 \%)$ foi positiva apenas para o HPV de baixo risco; e também uma $(2,5 \%)$ foi positiva apenas para o HPV de alto risco. Houve concordância entre todos os resultados positivos para presença de HPV-DNA nas amostras citológicas submetidas ao teste de captura híbrida Digene ${ }^{\circledR}$ e na leitura de esfregaço citológico ao microscópio óptico convencional. Desta forma, conclui-se que o vírus HPV pode comportar-se como mais um co-carcinógeno para o câncer de boca, à semelhança do carcinoma uterino. unitermos

Câncer oral

HPV

Citologia esfoliativo

Captura hibrida

1. Department of Pathology, Universidade de Pernambuco (UPE).

2. Department of Preventive and Social Dentistry/UPE.

3. Department of Pathology, Hospital do Câncer de Pernambuco; Department of Pathology, Universidade Federal de Pernambuco (UFPE).

4. Department of Pathologic Anatomy/UPE.

5. Department of Head and Neck, Hospital do Câncer de Pernambuco.

6. Technician of Laboratório Digene do Brasil, São Paulo. 


\section{Introduction}

Mouth cancer is among the ten most common forms of cancer worldwide. Owing to the high death rate for this type of neoplasm, it is one of the public health problems in Brazil whose indices have remained stable or even increased in some regions of the country in the past 40 years ${ }^{(14)}$.

Taking into consideration the etiology of mouth cancer, in which both endogenous and exogenous factors are involved, we set out, in the present study, to identify and verify its possible relationship with the human papilloma virus (HPV) in view of the influence of this virus in the causation of cervical carcinoma of the uterus $(7,10,18,21)$.

Dhariwal, Cubie and Southam(s) have stated that infections by HPV have been shown to be present in cancers of the mouth and also that the DNA of the Epstein-Barr virus (EBV) has likewise been isolated in these types of lesions, but there is no evidence of their direct action in the process of malign transformation of buccal epithelial cells ${ }^{(2)}$. Furthermore, Mao et al. ${ }^{(12)}$ have emphasized that the inactivation of the $\mathrm{p} 53$ protein is the most frequent genetic alteration found in human tumors, premalignant and malignant tumors of the buccal epithelium.

HPV is among the first viruses to be associated with neoplasms in humans. The initial evidence that HPV could cause cancer came from the study of epidermodysplasia verruciformis (EV), a rare disease characterized by multiple cutaneous lesions and immunity to defective cell measurement $^{(16)}$.

In 1974, Hausen et al. initiated studies that led to the discovery of HPV in carcinoma of the cervix, and other researchers throughout the world have now confirmed this association $(5,10,15,18)$. Malignancy in many other urogenital and oral locations has now also been related to $\mathrm{HPV}^{(3)}$

For Dhariwal, Cubie and Southam(5), the diagnosis of buccal infection by HPV should be based on a combination of the clinical features and the histopathological examinations.

Thus, the presence of HPV in oral cancers should be investigated, for it points to the action of the virus as a factor in the production of cancer of the mouth in parallel with genetic and/or other predisposing external factors such as smoking and alcohol, hence the importance of its detection as early as possible.

For this reason in the present study the aim is to verify the presence of low- and high-risk HPV in oral carcinomas by means of the hybrid capture tube test Digene ${ }^{\circledast}$ in samples collected by oral exfoliative cytology, a method recognized by a number of authors ${ }^{(8,19)}$ as effective for collecting material from the oral cavity. In addition, the other present external factors that may also predispose to the development of the disease are evaluated.

Emphasis is laid on the importance of this research as a tool in early diagnosis, thereby broadening the gamut of preventive resources for buccal lesions caused by HPV, a possible precursor of cancer of the mouth.

\section{Material and methods}

This was a cross-sectional study to identify HPV in oral carcinomas by means of samples obtained by exfoliative cytology (cytobrush), carried out in the Head and Neck Outpatient Clinic and the Department of Pathology of Hospital do Câncer de Pernambuco, the Integrated Center of Pathological Anatomy of Hospital Universitário Oswaldo Cruz of Universidade de Pernambuco, and Laboratório Digene do Brazil, in São Paulo.

The patients spontaneously attending Hospital do Câncer de Pernambuco, with diagnostic of oral carcinoma, were selected for the study, the purpose of which was to identify the virus in these lesions.

After freely signing their informed consent, 67 individuals comprised the initial sample. Of these, 14 failed to return to the clinic in good time to enable us to collect their material and forward it for analysis, and 13 had their collected material lost in the process of being transported owing to deficiencies in the conditioning of the material.

Thus the final sample consisted of 40 cytological specimens which were submitted to the hybrid capture tube test Digene ${ }^{\circledR}$ for the purposes of the study, all of which were from oral carcinomas of squamous cells before the start of the treatment.

A comparative assessment was made of the cytological conclusions indicative of a diagnosis of HPV in the conventional light microscope readings of the samples versus the accurate detection of the virus by hybrid capture in the cytological samples.

The 40 individuals who permitted the exfoliative cytology for conventional cytological diagnosis to be performed also contributed by supplying exfoliated material for the hybrid capture using Digene technology for identification of the HPV. 
Clinical/laboratory procedures: the initial step was the history taking and the completion of a clinical record card for the specific purpose of this study. This was followed by the extra- and intrabuccal examination and exfoliative cytology in the area of the lesion (shaving off the superficial layer of mucosa - cytobrush), followed by the preparation of the smear on slides with a frosted edge, duly identified and conditioned in plastic tubes containing the fixative: absolute alcohol PA for subsequent laboratory processing (Papanicolaou staining and hematoxylin/eosin). The slides were mounted at the integrated center of pathological anatomy (Ciap - Huoc/UPE) and submitted to conventional interpretation by light microscopy. Immediately after this initial exfoliative cytological collection a further, identical collection was made, in which the material still present in the bristles of the cytobrush was conditioned in the special Digene kit (with DNA-preserving solution) for detection of HPV and sent to São Paulo, where each laboratory phase for hybrid capture was performed.

The hybrid capture tube test is an examination processed by the technique of molecular hybridization, a Digene technology that uses nonradioactive probes with amplification of the detection of the hybrids by chemoluminescence. The material for analysis is denatured and reacts with a specific genic probe, forming RNA/DNA hybrids that are captured by antibodies lining the tube wall. Next, the immobilized hybrids react with antibodies specific for RNA/DNA conjugated to alkaline phosphatase forming a stable substract, and the hybrids are detected by ultrasensitive chemoluminescence. For the HPV the sensitivity on a microplate is $1 \mathrm{pg} / \mathrm{ml}$, equivalent to 0.1 virus copy per cell(20).

The hybrid capture tube test (Digene ${ }^{\circledast}$ technology) contains the genic probes of $70 \%$ of the types of low-risk HPV $-6,11,42,43,44-$, and $99 \%$ of the oncogenic types - 16, 18, 31, 33, 35, 39, 45, 51, 52, 56, 58, 59, 68. A negative result indicates the absence of DNA-HPV in the types studied ${ }^{(6)}$.

The hybrid capture tube test Digene ${ }^{\circledast}$ is a molecular biology test for HPV approved by the FDA and by the Brazilian Ministry of Health ${ }^{(6)}$.

It emphasizes that the reading is totally computerized, the chemoluminometer being controlled by software that analyzes the numbers received from the readings and performs all the validation calculations of the test. The test uses the readings from the controls for the validation and calculation of the cutoff (RLU = relative light unit/PCA or
$\mathrm{PCB}=$ positive control $\mathrm{A}$ and positive control $\mathrm{B} /$ cutoff obtained by the mean of the three positive controls).

The independent variables were age, gender, color, occupation, smoking, ethylism, the presence or absence of partial removable dental prostheses and the presence or absence of the HPV virus in the material collected; the dependent variable was the frequency of individuals with oral carcinomas.

A descriptive study was made of the data obtained in the present research.

\section{Results and discussion}

The final sample was made up of 40 cytological specimens from 40 oral carcinomas whose diagnoses confirmed the presence of well and moderately differentiated carcinomas of squamous cells ${ }^{(17)}$.

There was a $100 \%$ parity in the sample, since the same 40 subjects gave samples for exfoliative cytology by conventional cytological diagnosis and exfoliative material for the hybrid capture tube test for the identification of HPV using Digene ${ }^{\circledast}$ technology.

Of the $40(100 \%)$ subjects making up the final sample, $25(62.5 \%)$ were males and 15 females (37.5\%). The overall mean age was 45.2 years.

Among the males, 25 (100\%) were smokers, of whom 17 (68\%) also drank; among the females nine (60\%) smoked.

The findings corroborate those of the literature ${ }^{(14)}$ when they associate external factors such as exposure to the sun with the buccal lesions observed, mainly on the lower lip. For $15(60 \%)$ of the men were agricultural workers exposed to the sun, as well as smokers, and developed carcinomas of squamous cells on the lower lip and on the lateral edge of the tongue.

Of the $40(100 \%)$ cytological samples analyzed for the identification of HPV by the hybrid capture tube test, Digene $^{\circledR}$ technology, 29 (72.5\%) proved to be negative for the presence of low- and high-risk HPV; nine (22.5\%) were positive for low- and high-risk HPV; one (2.5\%) was positive only for low-risk HPV; and one was positive only for high-risk HPV (Table 1). In addition, the reading of the cytological smears by conventional light microscopy also signaled the presence of koilocytes, that is, alterations indicative of the presence of HPV in 13 of these samples (Table 2) ${ }^{(9)}$.

There was agreement between all positive results for the presence of low- and/or high-risk DNA-HPV in the material obtained by exfoliative cytology. 


\section{Results of the hybrid capture tube test, Digene ${ }^{\circledR}$ technology, for identification of HPV in oral}

Table 1 squamous cell carcinomas: material obtained by exfoliative cytology

\begin{tabular}{lccccc}
\hline Method used & Absence of & Presence of & Presence of & Presence of & Total \\
for obtaining & DNA-HPV & DNA-HPV & DNA-HPV & DNA-HPV & $n(\%)$ \\
sample & for the & for group A & for group B & for group A and B & \\
& types & (low-risk) & (high-risk) & (low- and high-risk) & \\
& studied & viruses & viruses & viruses & \\
\multicolumn{1}{l}{ Exfoliative cytology } & $29(72.5)$ & $n(\%)$ & $n(\%)$ & $n(\%)$ & \\
\hline
\end{tabular}

According to Jones et al. ${ }^{(8)}$, Sugerman and Savage ${ }^{(19)}$, exfoliative cytology, when well performed, is an efficient way of collecting material from the oral cavity. In fact, but this is true not only for diagnosis: it also permits the detection of the low- and/or high-risk DNA-HPV virus in the samples.

With regard to the 40 lesions studied that were diagnosed as being carcinomas of squamous cells, nine $(22.5 \%)$ presented a conclusive positive result for the presence of low- and high-risk DNA-HPV; as for the topographic location, six were situated on the lateral edge of the tongue; three were on the lower lip; one (2.5\%), whose finding was positive for low-risk DNA-HPV was situated on the lateral edge of the tongue; and one (2.5\%) that was positive for high-risk DNA-HPV was located in the region of the retromolar trigone.

The identification of the virus is important; however, epidemiological data by Lübbe et al. ${ }^{(11)}$ indicate that infection by high-risk HPV is not in itself enough for the development of cancer. It is known that there are, in fact, many other factors, e.g. smoking, ethylism, radiation, involved in the development of this neoplasm that are invariably present in persons suffering from cancer of the mouth, as shown by the findings of the present study and those of many others ${ }^{(14)}$. The authors believe that the presence of the HPV virus may also contribute to the development of this disease on the basis of reasons analogous to that of its action in cervicovaginal epithelium.

Epidemiological data indicate that infection by highrisk DNA-HPV is not by itself enough for the development of cancer of the mouth. It acts as a cocarcinogen, adding its effects to the many other factors, particularly smoking and ethylism. However, these findings show that one third of the patients with cancer of the mouth have DNA-HPV traces in the cancer cells.

Even considering the importance of smoking and ethylism as the main factors in the pathogenesis of oral cancer, the identification of the HPV assumes a significant role in the prevention of the disease, because it is not so easy to establish as the other factors and its actual incidence in the current literature is still not well determined.

The loss of the adenomatous gene of polyposis coli and human infection by the HPV virus in buccal carcinogenesis, highlighting the synergic role of tobacco and alcohol as the chief risk factors for the genesis of cancer of the mouth has been reported and, in addition, information has been produced on the association between buccal lesions involving the HPV virus and p-53 mutations, bearing in mind their locations ${ }^{(12)}$.

\section{Results of the reading of the cytological smear by conventional light microscopy,}

Table 2 for identification of HPV in oral squamous cell carcinomas

Method used for

obtaining sample

Exfoliative cytology
Absence of

DNA-HPV viruses

$$
n(\%)
$$

$27(67.5)$
Presence of DNA-HPV viruses

(presence of koilocytes)

$n(\%)$

13 (32.5)
Total

$n(\%)$

40 (100) 
Considering the finding of an absence of DNA-HPV (Tables 1 and 2) the authors believe that the absence of DNA-HPV for the types studied in 29 samples representing $72.5 \%$ of the material analyzed by hybrid capture tube test (Digene ${ }^{\circledR}$ technology) is actually due not only to the absence of the virus in some cases, but also to ten cytological collections that were clinically classed as unsatisfactory, but sent for analysis nonetheless.

As regards the anatomical site in the buccal cavity, of the 29 lesions classified with an absence of DNA-HPV for the types studied, 12 of the squamous cell carcinomas were situated on the lower lip, 11 on the lateral edge of the tongue, four on the floor of the mouth, one on the jugal mucus and one on the soft palate.

The anatomical site of occurrence of the lesions observed and diagnosed as squamous cell carcinomas was, in decreasing order, as follows: lateral edge of the tongue, lower lip, floor of the mouth, retromolar trigone region, jugal mucus and soft palate.

The findings demonstrate the presence of the low- and highrisk DNA-HPV virus by the hybrid capture tube test (Digene ${ }^{\circledR}$ technology) in moderately and well differentiated squamous cell carcinomas of the oral cavity, situated mainly on the lateral edge of the tongue and lower lip; however, Zeuss, Miller and White(22) report the identification of the HPV virus only in benign lesions of the oral cavity, such as condyloma acuminatum and verruca vulgaris, but not at all in premalignant and/or malignant lesions, while Atula et al. ${ }^{(2)}$; Dhariwal, Cubie and Southan ${ }^{(5)}$; Lübbe et al. ${ }^{(11)}$ and Mao et al. ${ }^{(12)}$ also identified HPVs 6 and 11 (low risk) associated with malignant tumors of the tonsils in a much greater frequency than is usually observed.

Further studies and research on the detection of the HPV virus in the buccal mucosa and its possible carcinogenic action are required, bearing in mind that it is present in over $90 \%$ of all invasive cervical carcinomas of the womb ${ }^{(7)}$. Prophylactic and therapeutic vaccines are being developed against HPV, like the vaccines against Helicobacter pylori, which is present in persons suffering from cancer of the stomach, which will add to the existing vaccines against the hepatitis $B$ and $C$ viruses present in cancer of the liver. These viruses represent $90 \%$ of all the infections associated with cancers in the developed countries ${ }^{(1,15)}$.

The results of this pilot study not only identified the presence or absence of DNA-HPV for the viruses of the three groups, $A, B$, and $A$ and $B$, but also attest to the validity of exfoliative cytology as a method able to provide suitable and sufficient material for the Hybrid Capture Tube Test ${ }^{\circledR}$, similarly to the identification of the virus in material obtained by exfoliative cytology from the uterus. In addition, they reveal that the properties of the Digene technology enable it to identify HPV in oral neoplasms.

It is thus concluded that the HPV virus may behave as one more cocarcinogen for cancer of the mouth, alongside smoking, ethylism, and the exposure to the sun, identified in our sample. Chen et al. ${ }^{(4)}$ showed that HPV 16 and betel quid chewing were two major risk factors for oral squamous cell carcinoma in their studies. We are, however, continuing with the present research so that we will be able to extrapolate the conclusions drawn from the findings of this initial study.

\section{Acknowledgements}

The authors wish to thank all those who allowed examinations to be performed in their oral cavities, thereby collaborating with the present study, and also the students of medicine and dentistry of Universidade de Pernambuco, professionals of the hospitals and laboratories where this research is being undertaken, and the invaluable support of the Universidade de Pernambuco's Institute of Biological Sciences and School of Dentistry and Laboratório Digene do Brasil, in São Paulo.

\section{References}

I. ARMSTRONG, B. Chemoprevention, WHO/OMS. 200 I (http: //www.who.int)

2. ATULA, S.; AUVINEN, E.; GRENMAN, R; SYRJANEN, S Human papillomavirus and Epstein-Barr virus in epithelia carcinomas of the head and neck region. Anticancer Res, v. 17(6D), p. 4427-33, 1997.

3. BOLWEB SOLUÇÕES INTERNET. HPV - 200 I Sociedade Brasileira de Informações de Patologias Urológicas. Available at: $<$ http://www.uronews.org.br>.
4. CHEN, P. C.; KUO, C.; PAN, C. C.; CHOU, M. Y. Risk of oral cancer associated with human papillomavirus infection, bete quid chewing, and cigarette smoking in Taiwan: an integrated molecular and epidemiological study of 58 cases.J Oral Pathol Med, v. 31, n. 6, p. 317-22, 2002.

5. DHARIWAL, S. K.; CUBIE, H. A.; SOUTHAN, J. C. Detection of human papillomavirus in oral lesions using commercially developed typing kits. Oral Microbiol Immunol, v. I0, p. 60-3, 1995. 
6. DIGENE. Diagnostics Inc. São Paulo, 1999.

7. IARC. Monographs on the evaluation of carcinogenic risk to humans. Human papillomaviruses, v. 64, 1995; viii+ 409 p. Available at: <http://www.who.int>.

8. JONES, A. C.; PINK, F. E.; SANDOW, P. L.; STEWART, C. M.; MIGLIORATI, C. A.; BAUGHMAN, R. A. The cytobrush plus cell collector in oral cytology. Oral Surg Oral Med Oral Pathol, v. 77, p. I01-4, 1994.

9. KOSS, L. G. Diagnostic cytology and its histopathologic bases. 3rd ed. JB Lippincott Co., 1979.

10. LEVINE, A. M. Epidemiology and clinical aspects of human papillomavirus: associated diseases. Program and Abstract of $5^{\text {th }}$ International Aids Malignancy Conference; April 23-25, 2001; Bethesda, Maryland.

I I. LÜBBE, J. et al. HPV-I I and HPV- I6: Associated oral verrucous carcinoma. Dermatology, v. 192, p. 217-21, 1996.

12. MAO, E-J.; SCHWARTZ, S. M.; DALING, J. R.; ODA, D.; TICKMAN, L.; BECKMANN, A. M. Human papilloma viruses and p53 mutations in normal, pre-malignant and malignant oral epithelia. Pred Oncol, v. 69, p. 152-258, 1996.

13. MILLER, C. S.; JOHNSTONE, B. M. Human papillomavirus as a risk factor for oral squamous cell carcinoma: a meta-analysis, 1982-1997. Oral Surg Oral Med Oral Pathol Oral Radiol Endod, v. 91, p. 622-35, 2001.

I4. MINISTÉRIO DA SAÚDE. O problema do câncer no Brasil. 4. ed. rev. e atual. Rio de Janeiro: INCa/Pró-Onco, 1997.
15. MUÑOZ, N. Prevention of cancers associated with infectious agents. WHO/OMS 200l. Available at: <http: //www.who.int>.

16. ROBBINS, S. L.; COTRAN, R. S.; KUMAR, V. Patologia estrutural e funcional. 4. ed. Rio de Janeiro: Guanabara Koogan, 1991.

17. ROSAI, J. Ackerman's surgical pathologies. Cap. 5: Oral cavity and oral pharynx. 7th ed. St. Louis, Missoury: Mosby Year Book Inc., 1996.

18. SCHIFFMAN, H. et al. Accuracy and interlaboratory reliability of human papillomavirus DNA testing by hybrid capture. Journal of Clinical Microbiology, p. 545-50, 1995.

19. SUGERMAN, P. B.; SAVAGE, N. W. Exfoliative cytology in clinical oral pathology. Australian Dental Journal, v. 4I, n. 2, p. 7I-4, 1996.

20. TAROMARU, E.; GALLO, C.; DÔRES, G. B. Captura híbrida. A nova metodologia em biologia molecular. $\bigcirc$ Biócito. Anatomia patológica, citopatologia, patologia clínica e ultrasonografia, n. I5, Ano IX, 1998.

21. TURAZZA, E. et al. Low-risk human papillomavirus types 6 and $\mid \mathrm{I}$ associated with carcinomas of genital and upper aero-digestive tract. Acta Obstet Gynecol Scand, v. 76, p. 27I-6, 1997.

22. ZEUSS, M. S.; MILLER, C. S.; WHITE, D. K. In situ hybridization analysis of human papillomavirus DNA in oral mucosal lesions. Oral Surg Oral Med Oral Pathol, v. 7I, n. 6, p. 7|4-20, |99|.

\section{Mailing address}

Aurora Karla de Lacerda Vidal

Rua João Eugênio de Lima 67/702 - Boa Viagem

CEP 51030-360 - Recife-PE

Tel.: (+55) (81) 3462-8178/9977-5529

e-mails: aurora.vida@@bol.com.br aurora.karla@bol.com.br 